\title{
Problem Management Teknologi Informasi Berdasarkan Kerangka Kerja ITIL V3 dan COBIT 5
}

\author{
Faried Effendy ${ }^{\mathrm{a}}$, Bahana Sukma Dewa ${ }^{\mathrm{b}}$, Eva Hariyanti $^{\mathrm{c}}$ \\ a,b,c Program Studi S1 Sistem Informasi, Fakultas Sains dan Teknologi, \\ Universitas Airlangga Surabaya
}

Naskah Diterima : 11 Juli 2018; Diterima Publikasi : 16 September 2018

DOI : $10.21456 /$ vol8iss2pp157-165

\begin{abstract}
In this research, developed Information Technology (IT) document of problem management for the export company. This document used as guidance for the company's employees to manage IT problem. Not every company's IT division has IT problem management strategy, the priority of problem-solving is usually done by the First In first out (FIFO) method by not considering the impact and the problem urgency. COBIT 5 and ITIL V3 DSS03 related to Problem management were used as standards to review and benchmark on how problem management activities should be done. The output of this research is a Standard Operating Procedure (SOP) document. The Problem management SOP document consists of three stages, the first stage is the preparation of SOP with 5 sub-stages, namely: list activity of ITIL V3 and COBIT 5 DSS03, mapping activity of ITIL V3 and COBIT 5 DSS03, verification of company new activities, mapping of activity actor based on RACI DSS02 and mapping of workproduct. The second stage is the adjustment of SOP documents with 2 sub-stages, namely: interviews for identification of needs and mapping of activity actor with the company's organizational structure. The third stage is the verification of SOP documents. The SOP documents contain 11 procedure with five actors. Overall SOP document can eventually become a reference for the company to manage IT problem.
\end{abstract}

Keywords: Problem Management; COBIT 5; ITIL V3; SOP.

\begin{abstract}
Abstrak
Dalam penelitian ini, dikembangkan dokumen Teknologi Informasi (TI) problem management untuk perusahaan ekspor. Dokumen ini digunakan sebagai panduan bagi karyawan perusahaan untuk mengelola permasalahan yang terkait dengan TI. Tidak semua divisi TI perusahaan memiliki strategi pengelolaan masalah TI, prioritas masalah biasanya dilakukan dengan metode First In First Out (FIFO) dengan tidak mempertimbangkan dampak dan masalah yang mendesak. ITIL V3 dan COBIT 5 DSS03 yang terkait dengan problem management digunakan sebagai standar untuk meninjau dan patokan tentang bagaimana kegiatan problem management seharusnya dilakukan. Output dari penelitian ini adalah dokumen Standard Operating Procedure (SOP). Penyusunan dokumen SOP problem management terdiri dari tiga tahap, tahap pertama adalah penyusunan SOP dengan 5 sub tahap yaitu: daftar aktifitas ITIL V3 dan COBIT 5 DSS03, pemetaan aktifitas ITIL V3 dan COBIT 5 DSS03, verifikasi aktivitas baru pada perusahaan, pemetaan aktor aktivitas berdasarkan RACI DSS03 dan pemetaan workproduct . Tahap kedua adalah penyesuaian dokumen SOP dengan 2 sub tahap yaitu: wawancara untuk identifikasi kebutuhan dan pemetaan aktor aktivitas dengan struktur organisasi perusahaan. Tahap ketiga adalah verifikasi dokumen SOP. Dokumen SOP yang dihasilkan berisi 11 prosedur dengan lima aktor dan secara keseluruhan dapat menjadi acuan bagi perusahaan untuk mengelola masalah IT.
\end{abstract}

Kata kunci: Problem Management; COBIT 5; ITIL V3; SOP.

\section{Pendahuluan}

Peranan Teknologi Informasi (TI) di berbagai sektor sudah tak dapat dipungkiri, banyak studi yang dapat berpendapat bahwa TI dapat meningkatkan kualitas layanan dan daya saing (Chen dan Tsou, 2007; Shestakevych, 2018). Manajemen layanan TI berperan dalam memahami kebutuhan pelanggan, pergerakan tren bisnis, dan pengambilan keputusan yang tepat berkaitan dengan penyampaian nilai

*) Penulis korespondensi: faried-e@ fst.unair.ac.id layanan TI (Megawati, 2012). Agar layanan TI dapat memberikan manfaat kepada pihak bisnis, layananlayanan TI tersebut harus terlebih dahulu di desain dengan acuan tujuan bisnis dari pelanggan (OGC, 2011b).

Hal ini juga mencegah munculnya keluhan dari pengguna dikemudian hari mengenai sistem yang tak memberikan hasil atau kinerja sesuai yang diharapkan. Manajemen layanan TI yang efektif dan efisien pada infrastruktur TI diperlukan untuk menghasilkan 
perbaikan yang signifikan terhadap kinerja bisnis dan penciptaan nilai tambah bagi end-user, salah satu proses yang ditawarkan dalam manajemen layanan TI adalah Problem management.

Problem (masalah) didefinisikan sebagai sesuatu yang menyebabkan terjadinya insiden. Problem management adalah proses yang bertanggung jawab untuk mengelola semua masalah pada siklus hidup layanan TI (OGC, 2011c). Tujuan utama dari Problem management adalah untuk mencegah masalah yang dapat menyebabkan insiden terjadi dan menghilangkan insiden yang berulang serta untuk meminimalkan dampak dari insiden yang tidak dapat dicegah. Problem management meliputi seluruh kegiatan yang dibutuhkan untuk mendiagnosa akar penyebab insiden dan menentukan resolusi untuk masalah tersebut.

SOP Problem management sebagai standar acuan untuk menangani permasalahan IT mutlak dibutuhkan perusahaan yang memiliki divisi TI. Strategi penanganan masalah, dokumentasi, prioritas masalah dan urgency dari masalah yang akan datang semuanya akan tercover didalam SOP Problem management. PT XYZ sebagai salah satu perusahaan ekspor di Surabaya belum memiliki strategi pengelolaan masalah TI, baik dari prioritas penanganan masalah maupun dokumentasi. Penelitian ini bertujuan menyusun SOP problem management menggunakan studi kasus PT XYZ menggunakan kombinasi kerangka COBIT 5 DSS03 dan ITIL V3.

ITIL dipilih karena merupakan suatu kerangka kerja yang konsisten dan komprehensif dari hasil implementasi yang teruji pada manajemen pelayanan TI salah satunya layanan Problem management sehingga suatu instansi dapat memenuhi tujuan standard kualitas layanan yang diinginkan. Kerangka kerja ITIL 2011 terdiri dari lima proses utama yaitu Service Strategy, Service Design, Service Transition, Service Operation, dan Continual Service Improvement (OGC, 2011a). COBIT merupakan suatu panduan best practice untuk Tata Kelola Teknologi Informasi yang dapat membantu auditor, pengguna (user), dan manajemen, untuk menjembatani kesenjangan antara risiko bisnis, kebutuhan kontrol, dan masalah-masalah teknis teknologi informasi.

COBIT 5 merupakan generasi terbaru dari panduan ISACA yang membahas mengenai tata kelola dan manajemen TI. Kerangka kerja COBIT 5 terdiri dari 5 domain yaitu Evaluate, Direct and Monitor, Align, Plan and Organize, Build, Acquire and Implement, Delivery, Service and Support, dan Monitor, Evaluate and Assess (ISACA, 2012).

\section{Kerangka Teori}

\subsection{ITIL}

ITIL (Information Technology Infrastructure Library) adalah kerangka kerja umum yang menggambarkan best practice dan IT Service
Management (ITSM). ITIL menyediakan panduan bagi penyedia layanan (service Provider) dalam mendukung penyediaan kualitas layanan TI dan proses, fungsi serta kapabilitas lainnya yang diperlukan. ITIL telah digunakan banyak organisasi dan menawarkan panduan best practice yang berlaku umum untuk semua organisasi yang menyediakan layanan.

ITIL bukanlah suatu standar yang harus diikuti, melainkan panduan yang harus dibaca dan dipahami serta digunakan untuk menciptakan nilai bagi penyedia layanan dan juga pelanggannya (Cabinet Office, 2011). ITIL juga menyediakan "wrapping" layanan dan fokus pada pengukuran dan perbaikan secara terus-menerus terhadap kualitas layanan TI yang diberikan, baik dari perspektif bisnis maupun perspektif pelanggan (IT Service Management Forum, 2007). Manfaat penerapan ITIL untuk organisasi antara lain:

a. Meningkatkan ketersediaan layanan (service availability) yang secara langsung berdampak pada meningkatnya keuntungan dan pendapatan bisnis.

b. Meningkatkan kepuasan pengguna dan pelanggan terhadap layanan TI.

c. Penghematan keuangan dari berkurangnya pekerjaan berulang, kehilangan waktu, serta peningkatan manajemen dan penggunaan sumber daya.

d. Mempercepat waktu peluncuran produk dan layanan baru ke konsumen.

e. Pengambilan keputusan yang lebih baik dan mengurangi risiko.

Kerangka kerja ITIL menyediakan struktur yang menerangkan layanan TI dalam bentuk siklus hidup (lifecycle). Pembuatan struktur dalam bentuk lifecycle ini untuk mempermudah pemahaman tahapan proses dan fungsi TI yang ada dalam ITIL.

\section{2. $C O B I T$}

COBIT (Control Objective for Information and Related Technology) merupakan kerangka kerja yang menyediakan solusi untuk tata kelola teknologi informasi melalui domain, proses, tujuan, kegiatan, model kematangan dan struktur yang logis dan teratur. Kerangka ini dapat membantu optimalisasi investasi yang berkaitan dengan teknologi informasi, menjamin penyampaian layanan dan memberikan alat ukur atau standar yang efektif untuk kepentingan manajemen dalam mengambil keputusan dalam organisasi. Target pengguna dari framework. COBIT adalah organisasi atau perusahaan dari berbagai latar belakang dan para profesional external assurance. Secara manajerial target pengguna COBIT adalah manajer, pengguna dan profesional TI serta pengawas dan pengendali profesional.

COBIT disusun oleh Information Systems Audit and Control Foundation (ISACA) pada tahun 1996. Edisi kedua dari COBIT diterbitkan pada tahun 1998. 
Pada tahun 2000 dirilis COBIT 3.0 oleh ITGI (Information Technology Governance Institute), COBIT 4.0 pada tahun 2005 dan COBIT 4.1 dirilis pada tahun 2007. Rilis terakhir COBIT 5 pada Juni tahun 2012. COBIT 5, membagi proses tata kelola dan manajemen TI suatu perusahaan atau organisasi menjadi dua area proses utama, yaitu:

a. Tata Kelola, memuat lima proses tata kelola, dimana akan ditentukan praktik-praktik dalam setiap proses evaluate, direct, and monitor (EDM).

b. Manajemen, memuat empat domain, sejajar dengan area tanggung jawab dari plan, build, run, and monitor (PBRM), dan menyediakan ruang lingkup TI yang menyeluruh dari ujung ke ujung (end-to-end).

Domain ini merupakan evolusi dari domain dan struktur proses dalam COBIT 4.1, yaitu:

a. Align, Plan, and Organize (APO), domain ini meliputi penyelarasan, perencanaan, dan pengaturan agar IT dapat berkontribusi untuk mencapai tujuan bisnis.

b. Build, Acquire, and Implement (BAI), domain ini meliputi membangun, memperoleh, dan mengimplementasikan sistem yang mendukung proses bisnis.

c. Delivery, Service and Support (DSS), meliputi mengirimkan, layanan, dan dukungan atau memberi pelayanan yang aktual bagi bisnis, termasuk manajemen data dan proteksi informasi yang berhubungan dengan proses bisnis.

d. Monitoring, Evaluation and Assess (MEA), domain ini terdiri dari pengawasan, evaluasi dan penilaian manajemen tentang pengendalian proses-proses, oleh lembaga monitoring independen yang berasal dari dalam dan luar organisasi atau lembaga alternatif lainnya.

\subsection{DSS 03 Manage Problems}

Salah satu domain yang terdapat pada COBIT 5 ialah DSS 03 Manage Problems yang mengidentifikasi dan mengklasifikasikan masalah dari akar penyebab dan memberikan resolusi yang tepat untuk mencegah insiden berulang (ISACA, 2012) Tujuan dari domain DSS 03 ialah meningkatkan ketersediaan, meningkatkan tingkat pelayanan, mengurangi biaya, dan meningkatkan kenyamanan dan kepuasan pelanggan dengan mengurangi jumlah masalah operasional (ISACA, 2012). Terdapat 5 Key Management Practice (KMP) yang dimiliki domain DSS 03 yaitu:

a. Identify and classify problems.

Mendefinisikan dan menerapkan kriteria dan prosedur untuk melaporkan masalah diidentifikasi, termasuk klasifikasi masalah, kategorisasi dan prioritas.

b. Investigate and diagnose problems.

Menyelidiki dan mendiagnosa masalah menggunakan ahli manajemen topik yang relevan untuk menilai dan menganalisa akar penyebab. c. Raise known errors.

Begitu akar penyebab masalah diidentifikasi, membuat catatan diketahui-kesalahan dan solusi yang tepat, dan mengidentifikasi solusi potensial.

d. Resolve and close problems.

Mengidentifikasi dan memulai solusi berkelanjutan mengatasi akar penyebab, meningkatkan permintaan perubahan melalui proses manajemen perubahan yang ditetapkan jika diperlukan untuk mengatasi kesalahan. Pastikan bahwa personil terpengaruh menyadari tindakan yang diambil dan rencana yang dikembangkan untuk mencegah insiden di masa depan dari terjadi.

e. Perform proactive problem management.

Mengumpulkan dan menganalisis data operasional (terutama insiden dan catatan perubahan) untuk mengidentifikasi kecenderungan yang muncul yang mungkin menunjukkan masalah. log catatan masalah untuk mengaktifkan penilaian.

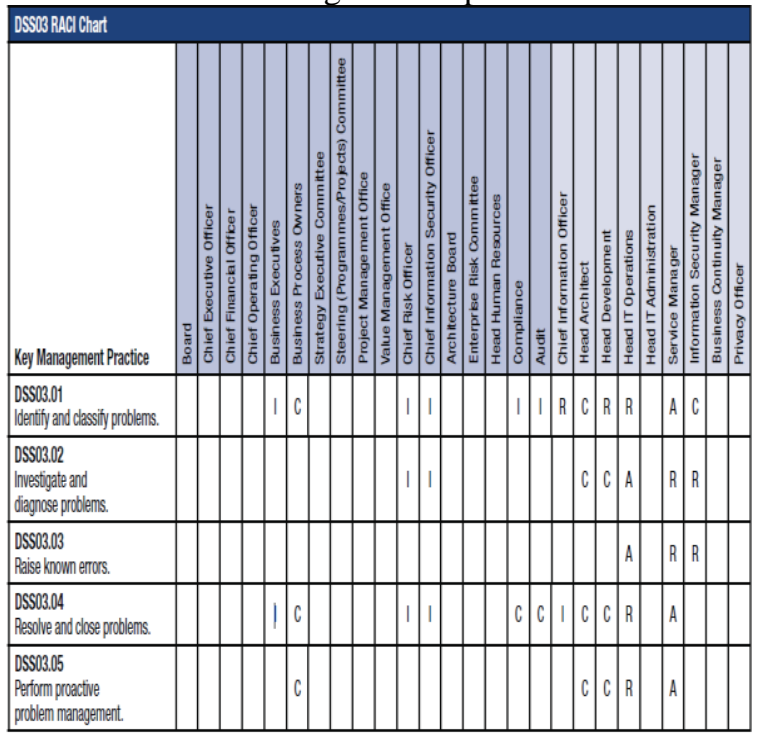

Gambar 1. Diagram RACI DSS 03(Putra et al., 2016)

\subsection{Diagram RACI DSS 03 Manage Problems}

Diagram RACI adalah bagian dari Responsibility Assignment Matrix (RAM), yaitu bentuk pemetaan antara sumber daya dengan aktivitas dalam setiap prosedur. RACI merupakan singkatan dari R (Responsible), A (Accountable), C (Consulted), dan I (Informed).Mapping dilakukan untuk seluruh control objective yang ada pada domain DSS. Dalam mapping tersebut diberi suatu nilai berupa R/A/C/I (Gambar 1), yang memiliki arti:

$\mathrm{R}$ (Responsible), berarti bahwa bagian tersebut merupakan pihak pelaksana yang harus bertanggung jawab melaksanakan dan menyelesaikan aktivitas yang menjadi tanggung jawabnya.

A (Accountable) berarti bahwa bagian tersebut merupakan pihak yang harus mengarahkan jalannya pelaksanaan aktivitas.

C (Consulted) berarti bahwa bagian tersebut merupakan pihak yang akan menjadi tempat konsultasi selama pelaksanaan aktivitas. 
I (Informed) berarti bahwa bagian tersebut merupakan pihak yang diberikan informasi mengenai pelaksanaan aktivitas.

\subsection{Pemetaan ITIL V3 dengan COBIT 5}

Pemetaan ITIL V3 dengan COBIT diperoleh dari pemetaan yang dilakukan oleh Glenfis AG sebuah perusahaan consulting dan training di Swiss yang bergerak dalam bidang Service Management dan IT Governance (Glenfis, 2012). Terdapat tabel pemetaan antara 37 proses COBIT 5 dengan 27 proses ITIL. Pemetaan ini menggunakan tanda silang (X) untuk menunjukan bahwa adanya relasi antara proses COBIT 5 dengan proses ITIL

\section{Metode}

\subsection{Tahapan Penelitian}

Tahapan penelitian yang digunakan dapat dilihat pada Gambar 2.

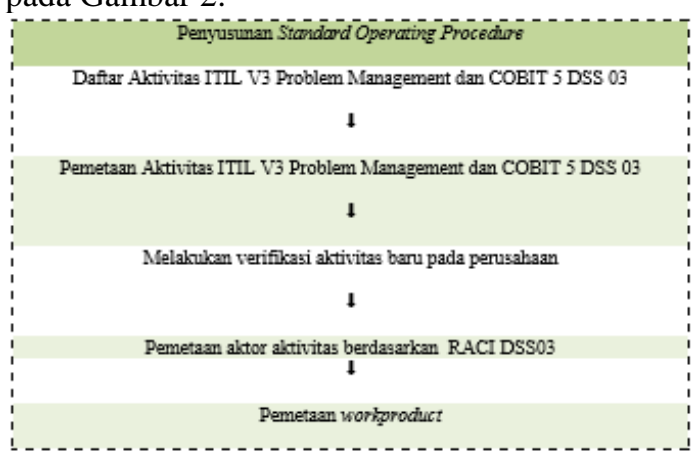

1

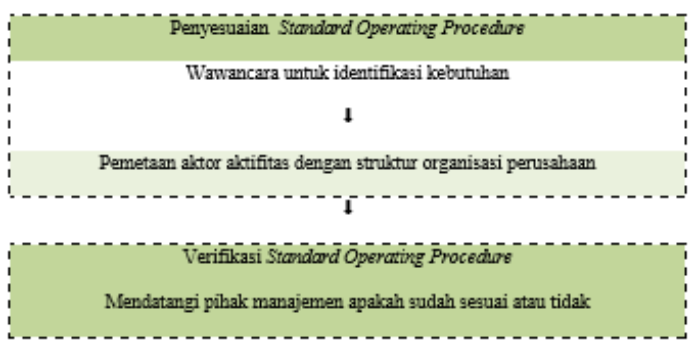

Gambar 2. Metode penelitian

\subsection{Penyusunan SOP}

Dalam penyusunan format SOP tidak terdapat format baku karena didasarkan pada tujuan dari pembuatan SOP tersebut (Budihardjo, 2014). Terdapat lima sub-tahap dalam penyusunan SOP yaitu: pendaftaran aktifitas ITIL V3 dan COBIT 5 DSS03, pemetaan aktifitas ITIL V3 dan COBIT 5 DSS03, verifikasi aktifitas baru pada perusahaan, pemetaan aktor aktivitas berdasarkan RACI DSS03, dan pemetaan workproduct. Output dari tahap terakhir ialah berupa SOP yang bersifat umum.

1. Daftar Aktivitas ITIL V3 Problem management dan COBIT 5 DSS 03. Daftar aktivitas COBIT 5 DSS 03 diperoleh dari Key Performance Indicator (KPI) yang terdapat pada COBIT Process Asessment Model, sedangkan daftar aktivitas
Problem management diperoleh dari ITIL Problem management. Ada perbedaan antara COBIT 5 DSS 03 dan ITIL Problem management, jika pada COBIT semua proses sudah didefinisikan dengan jelas yang dibedakan menjadi tiap-tiap proses pengelolaan insiden. Lain dengan ITIL Incident Management, tiap-tiap proses pada ITIL didefinisikan secara narasi untuk mengetahui proses pengelolaan insiden. Oleh karena itu harus diaambil inti sari dari narasi yang terdapat pada ITIL Problem management.

2. Pemetaan Aktifitas ITIL V3 Problem management \& COBIT 5 DSS0. Pemetaan aktivitas ITIL V3 dengan COBIT 5 didapatkan dari panduan COBIT 5: Enabling Process pada bagian related guidance di setiap proses COBIT 5. Setelah dilakukan pemetaan didapat aktivitas ITIL V3 Service Operation bagian Problem management yang berdekatan langsung dengan proses domain COBIT 5 DSS 03 Manage problems.

3. Melakukan verifikasi aktivitas baru pada perusahaan. Verifikasi dilakukan untuk mengetahui apakah aktifitas baru hasil kombinasi COBIT 5 DSS03 dan ITIL Problem Management sesuai, dapat dipahami dan dapat diterapkan di perusahaan.

4. Verifikasi dilakukan dengan cara wawancara dan pengisian kuisioner, teknis melakukan wawancara ialah dengan membahas secara langsung dokumen aktifitas baru yang telah disusun. Wawancara dilakukan bertujuan untuk mengetahui tanggapan langsung apakah aktifitas tersebut dapat dilakukan atau tidak, serta mengetahui alasan jika salah satu aktifitas tidak dapat dilakukan pada perusahaan.

5. Pemetaan aktor aktivitas berdasarkan RACI DSS03. Pemetaan dilakukan bertujuan untuk mengetahui aktor yang bertanggung jawab melakukan tiap-tiap aktifitas pengelolaan masalah. Pada dasarnya ITIL Problem Management tidak memiliki panduan untuk melakukan pemetaan aktifitas, untuk mengetahui aktor dari aktifitas ITIL Problem management maka dilakukan pemetaan tiap aktifitasnya dengan aktifitas yang ada di COBIT 5 DSS 03.Setelah dilakukan pemetaan aktifitas maka aktor disesuaikan dengan RACI Chart.

6. Pemetaan workproduct. Pemetaan work product dilakukan untuk keperluan dokumentasi setiap aktifitas. Work product diperoleh dari COBIT 5 Process Assesment Model (PAM), pada umumnya setiap aktifitas akan menghasilkan suatu dokumen kerja atau laporan.

\subsection{Penyesuaian Dokumen SOP}

Dokumen SOP yang dihasilkan dari tahap sebelumnya masih bersifat umum. Untuk memastikan kesesuaian dokumen SOP yang dibangun dengan studi kasus perusahaan maka dilakukan penyesuaian dokumen SOP yang telah dibuat dengan kebutuhan 
perusahaan, struktur organisasi dengan RACI Chart, dan proses bisnis yang dimiliki perusahaan. Ada 2 sub-tahap dalam penyesuaian dokumen SOP yaitu: wawancara identifikasi kebutuhan dan pemetaan aktor aktivitas dengan struktur organisasi perusahaan.

1. Wawancara identifikasi kebutuhan. Kegiatan wawancara dilakukan untuk mendapatkan akar permasalahan mengenai problem management di perusahaan, sementara identifikasi kebutuhan digunakan untuk mengetahui karakteristik proses bisnis perusahaan, struktur organisasi, dukungan TI seperti (Hardware, Software, Infrastruktur TI, Sistem Operasi, SDM TI).

2. Pemetaan aktor aktivitas dengan struktur organisasi perusahaan. Pemetaan ini bertujuan untuk menyesuaikan aktor pelaksana aktivitas yang telah dibuat pada proses sebelumnya dengan struktur organisasi yang ada pada perusahaan.

\subsection{Verifikasi Dokumen SOP}

Setelah dokumen SOP problem management selesai maka akan dilakukan verifikasi melihat kembali kesesuaian SOP problem management yang dibangun dengan struktur organisasi, problem management yang dimiliki perusahaan, keadaan normal aktivitas sistem, dan keadaan TI perusahaan. Dokumen SOP problem management diverifikasi bertujuan untuk mengetahui sejauh mana kesesuaian problem management dengan kebutuhan perusahaan dan bertujuan untuk mengetahui sejauh mana kesesuaian aktivitas-aktivitas dalam dokumen untuk memenuhi prosedur kerja jika terjadi masalah. Diperlukan wawancara untuk mengatahui umpan balik dari pihak TI dan manajemen perusahaan.

\section{Hasil dan Pembahasan}

\subsection{Penyusunan SOP}

\subsubsection{Daftar Aktivitas ITIL V3 Problem management} dan COBIT 5 DSS 03

Daftar aktifitas yang terdapat pada KMP COBIT 5 menghasilkan 5 proses aktifitas COBIT 5 DSS 03 Manage Problems dan 10 proses aktifitas ITIL Problem management. Daftar aktifitas COBIT DSS 03 dapat dilihat pada COBIT 5 Enabling Processes (ISACA, 2012) dan daftar aktifitas ITIL Problem management dapat dilihat pada Tabel 1.

\subsubsection{Pemetaan Aktifitas ITIL V3 Problem management dan COBIT 5 DSSO3}

COBIT 5 DSS 03 dan ITIL Problem management dipetakan berdasarkan urutan proses ITIL Incident Management. Terdapat 10 urutan proses pengelolaan insiden menurut ITIL yaitu Problem detection, problem logging, problem categorization, incident priorization, Problem Investigation and Diagnosis, Workarounds, Raising a Known Error Record, Problem resolution, Problem Closure, Major Problem
Review. Aktivitas yang telah dipetakan dapat dilihat pada Tabel 2.

Tabel 1. Aktivitas ITIL incident management ITIL Problem management

\begin{tabular}{ll}
\hline $\begin{array}{l}\text { Aktifitas ITIL Problem } \\
\text { management }\end{array}$ & KODE \\
$\begin{array}{l}\text { Problem detection (PD) } \\
\text { Incident logging (IL) }\end{array}$ & PD-1, PD-2, PD-3 \\
$\begin{array}{l}\text { Incident categorization (IC) } \\
\text { Incident priorization (IP) }\end{array}$ & IC-1 \\
$\begin{array}{l}\text { Problem Investigation } \\
\text { Diagnosis(PI) }\end{array}$ & IP-1,IP-2 \\
$\begin{array}{l}\text { Workarounds (WO) } \\
\begin{array}{l}\text { Raising a Known Error Record } \\
\text { (RK) }\end{array}\end{array}$ & RK-1, PI-2, PI-3 \\
$\begin{array}{l}\text { Problem resolution (PR) } \\
\text { Problem Closure (PC) } \\
\text { Major Problem Review (MP) }\end{array}$ & PR-1,PR-2,PR3 \\
\hline
\end{tabular}

Tabel 2. Pemetaan Aktivitas ITIL dan COBIT5

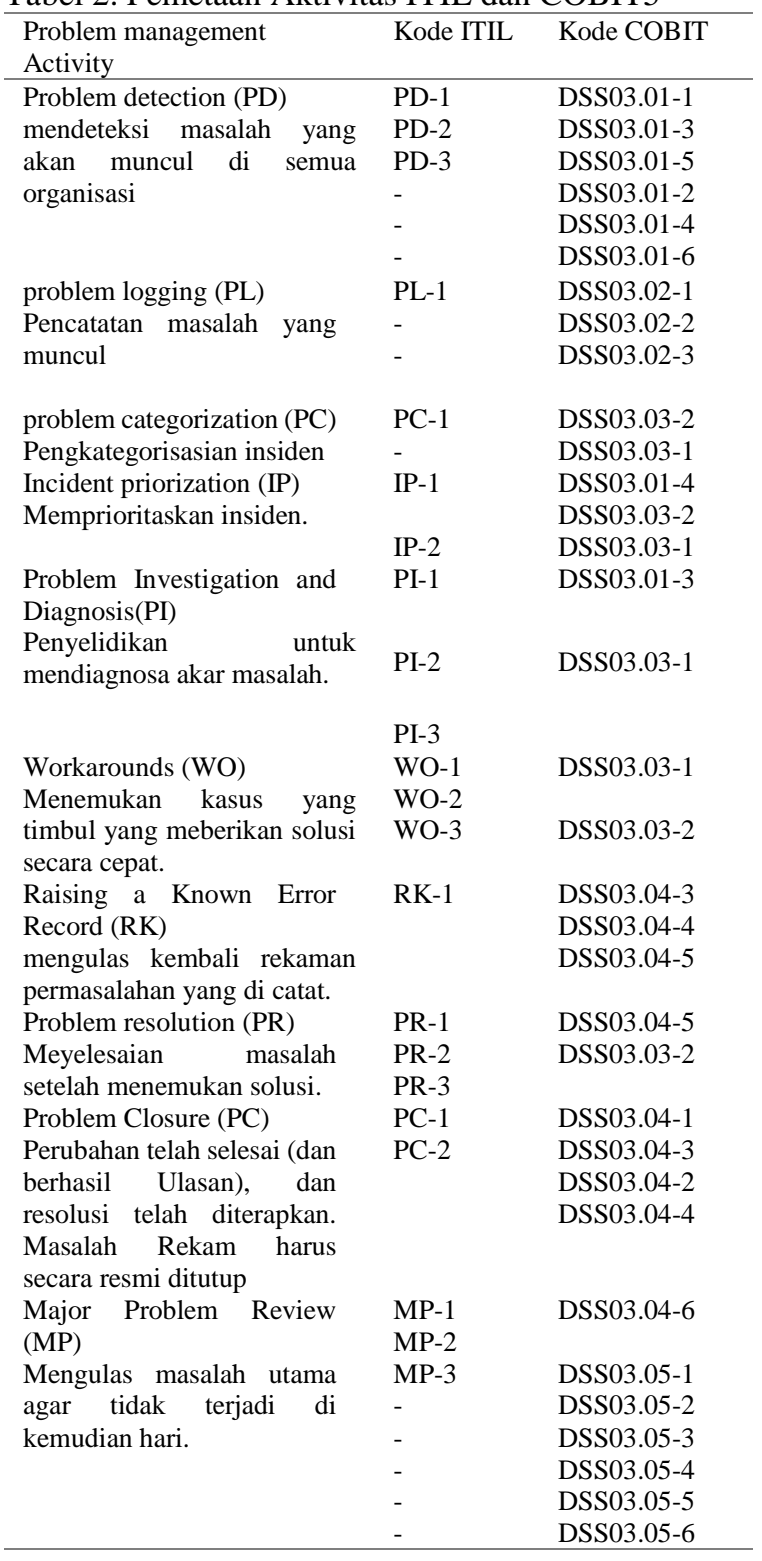


4.1.3. Melakukan verifikasi aktifitas baru pada perusahaan

Kombinasi COBIT 5 DSS03 dan ITIL Problem management menghasilkan aktivitas baru yang belum tentu sesuai dan dapat diterapkan di perusahaan. Oleh karena itu, perlu dilakukan verifikasi untuk mengetahui apakah aktifitas baru tersebut dapat diterapkan di perusahaan. Aktivitas baru hasil kombinasi dapat dilihat pada Tabel 3.

Tabel 3. Aktivitas yang telah dikombinasikan

\begin{tabular}{|c|c|c|}
\hline \multicolumn{3}{|c|}{ [1]. Problem detection (PD) } \\
\hline Langkah & Kode Aktifitas ITIL \& COBIT 5 & $\begin{array}{c}\text { Kode } \\
\text { Aktifitas }\end{array}$ \\
\hline 1 & PD-1, DSS03.01-1 & AA-1 \\
\hline 2 & PD-2, DSS03.01-3 & AA-2 \\
\hline 3 & PD-3, DSS03.01-5 & AA-3 \\
\hline 4 & DSS03.01-2 & AA-4 \\
\hline 5 & DSS03.01-4 & AA-5 \\
\hline 6 & DSS03.01-6 & AA-6 \\
\hline \multicolumn{3}{|c|}{ [2]. Problem logging (PL) } \\
\hline 1 & PL-1, DSS03.02-1 & BB-1 \\
\hline 2 & DSS03.02-2 & BB-2 \\
\hline 3 & DSS03.02-3 & BB-3 \\
\hline \multicolumn{3}{|c|}{ [3]. problem categorization $(\mathrm{PC})$} \\
\hline 1 & PC-1, DSS03.03-2 & CC-1 \\
\hline 2 & DSS03.03-1 & $\mathrm{CC}-2$ \\
\hline \multicolumn{3}{|c|}{ [4]. Incident priorization (IP) } \\
\hline 1 & IP-1, DSS03.01-4, DSS03.03-2 & DD-1 \\
\hline 2 & IP-2, DSS03.03-1 & DD-2 \\
\hline \multicolumn{3}{|c|}{ [5]. Problem Investigation and Diagnosis (PI) } \\
\hline 1 & PI-1, DSS03.01-3 & EE-1 \\
\hline 2 & PI-2, PI-3, DSS03.03-1 & EE-2 \\
\hline \multicolumn{3}{|c|}{ [6]. Workarounds (WO) } \\
\hline 1 & WO-1, WO-2, DSS03.03-1 & FF-1 \\
\hline 2 & WO-3, DSS03.03-2 & FF-2 \\
\hline \multicolumn{3}{|c|}{ [7]. Raising a Known Error Record (RK) } \\
\hline 1 & $\begin{array}{l}\text { RK-1, DSS03.04-3, DSS03.04- } \\
4 \text {, DSS03.04-5 }\end{array}$ & GG-1 \\
\hline \multicolumn{3}{|c|}{ [8]. Problem resolution (PR) } \\
\hline 1 & PR-1, DSS03.04-5 & HH-1 \\
\hline 2 & PR-2, PR-3, DSS03.03-2 & HH-2 \\
\hline \multicolumn{3}{|c|}{ [9].Problem Closure (PC) } \\
\hline 1 & PC-1, DSS03.04-1 & II-1 \\
\hline 2 & $\begin{array}{l}\text { PC-2, DSS03.04-3, DSS03.04-2, } \\
\text { DSS03.04-4 }\end{array}$ & III-2 \\
\hline \multicolumn{3}{|c|}{ [10]. Major Problem Review (MP) } \\
\hline 1 & MP-1, MP-2, DSS03.04-6 & $\mathrm{JJ}-1$ \\
\hline 2 & MP-3, DSS03.05-1 & $\mathrm{JJ}-2$ \\
\hline 3 & DSS03.05-2 & $\mathrm{JJ}-3$ \\
\hline 4 & DSS03.05-3 & JJ-4 \\
\hline 5 & DSS03.05-4 & $\mathrm{JJ}-5$ \\
\hline 6 & DSS03.05-5 & JJ-6 \\
\hline 7 & DSS03.05-6 & $\mathrm{JJ}-7$ \\
\hline
\end{tabular}

Aktifitas baru yang akan diverifikasi berjumlah 10 aktifitas dengan 29 langkah kerja. Judul aktifitas tersebut yaitu: Identifikasi Masalah (Problem detection), Pencatatan masalah yang muncul (Problem Logging), Pengkategorian masalah (Problem Categorization), Memprioritaskan Insiden (Incident
Priorization), Investigasi dan diagnosa masalah (Problem investigation and diagnosis), Menemukan Solusi (Workarounds), Mengulas kembali rekaman permasalahan yang dicatat (Rasing a known error record), Meyelesaian masalah setelah menemukan solusi (Problem Resolution), Penutupan Masalah (Problem Closure), dan Mengulas masalah utama (Major problem review).

Dari hasil verifikasi didapatkan tanggapan positif dari pihak perusahaan, dan aktivitas baru yang telah dirancang siap diterapkan di lingkungan perusahaan.

Tabel 4. Pemetaan aktor aktivitas

\begin{tabular}{|c|c|c|c|c|c|}
\hline $\begin{array}{c}\text { Kode } \\
\text { Aktifitas }\end{array}$ & A & B & C & D & E \\
\hline AA-1 & $\mathrm{R}$ & $\mathrm{R}$ & $\mathrm{R}$ & & \\
\hline AA-2 & $\mathrm{R}$ & $\mathrm{R}$ & $\mathrm{R}$ & & \\
\hline AA-3 & $\mathrm{R}$ & $\mathrm{R}$ & $\mathrm{R}$ & & \\
\hline AA-4 & $\mathrm{R}$ & $\mathrm{R}$ & $\mathrm{R}$ & & \\
\hline AA-5 & $\mathrm{R}$ & $\mathrm{R}$ & $\mathrm{R}$ & & \\
\hline AA-6 & $\mathrm{R}$ & $\mathrm{R}$ & $\mathrm{R}$ & & \\
\hline BB-1 & & & & $\mathrm{R}$ & $\mathrm{R}$ \\
\hline BB-2 & & & & $\mathrm{R}$ & $\mathrm{R}$ \\
\hline BB-3 & & & & $\mathrm{R}$ & $\mathrm{R}$ \\
\hline CC-1 & & & & $\mathrm{R}$ & $\mathrm{R}$ \\
\hline CC-2 & & & & $\mathrm{R}$ & $\mathrm{R}$ \\
\hline DD-1 & $\mathrm{R}$ & $\mathrm{R}$ & $\mathrm{R}$ & $\mathrm{R}$ & $\mathrm{R}$ \\
\hline DD-2 & & & & $\mathrm{R}$ & $\mathrm{R}$ \\
\hline EE-1 & $\mathrm{R}$ & $\mathrm{R}$ & $\mathrm{R}$ & & \\
\hline EE-2 & & & & $\mathrm{R}$ & $\mathrm{R}$ \\
\hline FF-1 & & & & $\mathrm{R}$ & $\mathrm{R}$ \\
\hline FF-2 & & & & $\mathrm{R}$ & $\mathrm{R}$ \\
\hline GG-1 & & & $\mathrm{R}$ & & \\
\hline HH-1 & & & $\mathrm{R}$ & & \\
\hline $\mathrm{HH}-2$ & & & & $\mathrm{R}$ & $\mathrm{R}$ \\
\hline II-1 & & & & $\mathrm{R}$ & $\mathrm{R}$ \\
\hline II-2 & & & & $\mathrm{R}$ & $\mathrm{R}$ \\
\hline JJ-1 & & & & $\mathrm{R}$ & $\mathrm{R}$ \\
\hline $\mathrm{JJ}-2$ & & & $\mathrm{R}$ & & \\
\hline $\mathrm{JJ}-3$ & & & $\mathrm{R}$ & & \\
\hline JJ-4 & & & $\mathrm{R}$ & & \\
\hline JJ-5 & & & $\mathrm{R}$ & & \\
\hline JJ-6 & & & $\mathrm{R}$ & & \\
\hline JJ-7 & & & $\mathrm{R}$ & & \\
\hline
\end{tabular}

Keterangan :

A : Chief information officer $\quad C:$ Head IT operation

B : Head development D : Service manager

$\mathrm{E}:$ Information security manager

\subsubsection{Pemetaan Aktor Aktifitas Berdasarkan RACI} CHART COBIT 5 dan ITIL

Pemetaan aktor aktifitas sesuai dengan RACI Chart COBIT 5 DSS03. Pemetaan dilakukan bertujuan untuk mengetahui aktor yang bertanggung jawab melakukan tiap-tiap aktifitas problem management. Pada dasarnya ITIL Problem management tidak memiliki panduan untuk melakukan pemetaan aktifitas, untuk mengetahui aktor dari aktifitas ITIL Problem management maka dilakukan pemetaan tiap aktifitasnya dengan aktifitas 
yang ada di COBIT 5 DSS 03. Hasil pemetaan dapat dilihat pada Tabel 4 .

\subsubsection{Pemetaan Work Product}

Pemetaan work product dilakukan untuk keperluan dokumentasi setiap aktifitas. Work product diperoleh dari COBIT 5 Process Assesment Model (PAM), pada umumnya setiap aktifitas akan menghasilkan suatu dokumen kerja atau laporan.

Untuk mengetahui dokumen yang dihasilkan dari setiap aktifitas maka digunakan work product COBIT 5 sebagai acuan pemetaan ke tiap aktifitas problem management. Dapat dilihat pada Tabel 5.

Tabel 5. Pemetaan work product

\begin{tabular}{|c|c|c|c|}
\hline $\mathrm{NO}$ & $\begin{array}{l}\text { Hasil Kerja (Work } \\
\text { Product) }\end{array}$ & $\begin{array}{l}\text { Kode Hasil } \\
\text { Kerja } \\
\text { COBIT } 5\end{array}$ & $\begin{array}{l}\text { Kode } \\
\text { Aktifitas }\end{array}$ \\
\hline 1 & $\begin{array}{l}\text { Catatan Skema klasifikasi } \\
\text { masalah }\end{array}$ & $\begin{array}{l}\text { DSS03- } \\
\text { WP1 }\end{array}$ & $\begin{array}{l}\text { AA-1, AA-2, } \\
\text { AA-5, CC-1, } \\
\text { DD-1, EE-1, } \\
\text { EE-2 }\end{array}$ \\
\hline 2 & $\begin{array}{l}\text { Catatan Status laporan } \\
\text { masalah }\end{array}$ & $\begin{array}{l}\text { DSS03- } \\
\text { WP2 }\end{array}$ & $\begin{array}{l}\text { AA-1, AA-3, } \\
\text { AA-4, AA-5, } \\
\text { BB-3 }\end{array}$ \\
\hline 3 & Catatan daftar masalah & $\begin{array}{l}\text { DSS03- } \\
\text { WP3 }\end{array}$ & $\begin{array}{l}\text { AA-1, AA-6, } \\
\text { BB-2, CC-2, }\end{array}$ \\
\hline 4 & $\begin{array}{l}\text { Catatan akar penyebab } \\
\text { masalah }\end{array}$ & $\begin{array}{l}\text { DSS03- } \\
\text { WP4 }\end{array}$ & $\begin{array}{l}\text { AA-2,AA-5, } \\
\text { DD-2 }\end{array}$ \\
\hline 5 & $\begin{array}{l}\text { Catatan laporan resolusi } \\
\text { masalah }\end{array}$ & $\begin{array}{l}\text { DSS03- } \\
\text { WP5 }\end{array}$ & $\begin{array}{l}\text { CC-1, FF-1, } \\
\text { HH-2 }\end{array}$ \\
\hline 6 & $\begin{array}{l}\text { Catatan kesalahan yang } \\
\text { diketahui }\end{array}$ & $\begin{array}{l}\text { DSS03- } \\
\text { WP6 }\end{array}$ & $\begin{array}{l}\text { AA- } 6, \text { BB- } \\
1, \text { CC- } 2\end{array}$ \\
\hline 7 & $\begin{array}{l}\text { Catatan usulan solusi } \\
\text { untuk kesalahan yang di } \\
\text { ketahui }\end{array}$ & $\begin{array}{l}\text { DSS03- } \\
\text { WP7 }\end{array}$ & $\begin{array}{l}\text { AA-2, DD- } \\
2, \text { EE-2, FF- } \\
2, \text { HH-2, II-1 }\end{array}$ \\
\hline 8 & $\begin{array}{l}\text { Catatan masalah yang telah } \\
\text { selesai }\end{array}$ & $\begin{array}{l}\text { DSS03- } \\
\text { WP8 }\end{array}$ & FF-2, HH-1 \\
\hline 9 & $\begin{array}{l}\text { Catatan komunikasi dari } \\
\text { pembelajaran }\end{array}$ & $\begin{array}{l}\text { DSS03- } \\
\text { WP9 }\end{array}$ & $\begin{array}{l}\text { JJ-1, JJ-2, JJ- } \\
3, \text { JJ-7 }\end{array}$ \\
\hline 10 & $\begin{array}{l}\text { Catatan laporan } \\
\text { pemantauan penyelesaian } \\
\text { masalah }\end{array}$ & $\begin{array}{l}\text { DSS03- } \\
\text { WP10 }\end{array}$ & $\begin{array}{l}\text { GG-1，JJ-6, } \\
\text { JJ-7 }\end{array}$ \\
\hline 11 & $\begin{array}{l}\text { Catatan solusi } \\
\text { berkelanjutan yang } \\
\text { teridentifikasi }\end{array}$ & $\begin{array}{l}\text { DSS03- } \\
\text { WP11 }\end{array}$ & $\begin{array}{l}\text { GG-1, II-2, } \\
\text { JJ-3, JJ-4, JJ- } \\
5, \text { JJ-7 }\end{array}$ \\
\hline
\end{tabular}

\subsection{Penyesuaian Dokumen SOP}

Dokumen SOP yang dibangun masih bersifat umum untuk diterapkan ke organisasi perusahaan sehingga diperlukan penyesuaian. Untuk melakukan penyesuaian diperlukan informasi pendukung sebagai dasar melakukan penyesuaian. Penyesuaian terdiri dari 2 tahap yakni identifikasi kebutuhan dan penyesuaian aktor aktivitas.

1. Identifikasi Kebutuhan

Identifikasi kebutuhan dilakukan wawancara dengan salah satu staff TI perusahaan. Titik permasalahan pada informasi yang diperoleh ialah pada problem management perusahaan. Pertama strategi problem management yang dimiliki sangat jauh dari pedoman yang berlaku seperti ITIL Problem management hal ini disebabkan karena tim TI kurang memiliki kesadaran pentingnya problem management ditambah keterbatasan pengetahuan terkait problem management sesuai standart yang berlaku.

Dari 10 proses utama problem management yang terdapat pada ITIL Problem management hanya terdapat 3 proses yang telah dilakukan perusahaan untuk mengelola masalah yakni Identifikasi, Investigasi, dan Resolusi. Jika dilihat lebih jauh pada tahap identifikasi yang dimiliki perusahaan sangat jauh dari dokumen SOP proses identifikasi masalah yang telah disusun sebelumnya. Terdapat 3 proses identifikasi pada dokumen SOP problem management sementara proses tahap problem management yang dimiliki perusahaan tidak jelas bahkan tidak adanya dokumen tertulis begitu juga dengan tahap investigasi dan resolusi.

\section{Pemetaan Aktor Aktivitas}

Untuk melakukan pemetaan aktor aktifitas diperlukan aktifitas problem management yang sudah ditentukan aktornya sesuai RACI Chart dan struktur organisasi perusahaan yang berkepentingan untuk menjalankan proses problem management. Sesuai RACI Chart COBIT 5 DSS 03 terdapat 5 aktor responsible sebagai peran alternatif problem management yaitu: Chief information officer, Head IT Operations, Head Development, Service manager, Information security manager. Aktor responsible tersebut akan dipetakan ke struktur organisasi perusahaan. Berdasarkan informasi yang diperoleh terdapat 5 aktor struktur organisasi perusahaan yang nantinya akan menjalankan proses problem management yaitu General Manager, IT Document, IT Manager, IT Support Officer, dan IT Programmer. Setelah mengetahui deskripsi actor dari RACI Chart dan struktur organisasi perusahaan langkah selanjutnya melakukan pemetaan actor. Pemetaan dilakukan berdasarkan kecocokan deskripsi kerja aktor RACI Chart dan struktur organisasi perusahaan. Usulan pemetaan aktor dapat dilihat pada Tabel 6 di bawah ini.

Tabel 6. Pemetaan Aktor Aktivitas Perusahaan

\begin{tabular}{llll}
\hline No & $\begin{array}{l}\text { Struktur } \\
\text { Organisasi } \\
\text { RACI Chart } \\
\text { COBIT 5 }\end{array}$ & $\begin{array}{l}\text { Struktur } \\
\text { Organisasi }\end{array}$ & Keterangan \\
& PERUSAHAAN & \\
\hline 1 & $\begin{array}{l}\text { Chief information } \\
\text { officer }\end{array}$ & General Manager & Non TI \\
& & IT Document & TI \\
2 & IT Manager & TI \\
& Dead & IT Manager & TI \\
3 & Head IT & IT Support Officer & TI \\
4 & Operations & IT Programmer & TI \\
5 & Service Manager & IT Support Officer & TI \\
& Information & IT Manager & TI \\
\hline
\end{tabular}

\subsection{Verifikasi Dokumen SOP}

Penyesuaian dokumen SOP dilakukan dengan cara wawancara, teknis melakukan wawancara ialah dengan membahas secara langsung dokumen SOP yang telah disusun dengan aktor pilihan antara lain General Manager, IT Document, IT Manager, IT 
Programmer, IT Support Officer. Hasil verifikasi dapat dilihat pada Tabel 7.

Tabel 7. Aktivitas Peran Problem management

\begin{tabular}{|c|c|c|c|}
\hline No & Aktor & Nama Aktivitas & Jumlah \\
\hline 1 & $\begin{array}{l}\text { General } \\
\text { Manager }\end{array}$ & Memprioritaskan Insiden & 1 \\
\hline \multicolumn{2}{|c|}{ Total aktivitas } & & 1 \\
\hline 2 & $\begin{array}{l}\text { IT } \\
\text { Document }\end{array}$ & Idenfikasi Masalah & 2 \\
\hline \multicolumn{2}{|c|}{ Total aktivitas } & & 2 \\
\hline \multirow[t]{4}{*}{3} & IT Manager & Idenfikasi Masalah & 2 \\
\hline & & Pengkategorian masalah & 1 \\
\hline & & $\begin{array}{l}\text { Investigasi dan } \\
\text { mendiagnosa masalah }\end{array}$ & 1 \\
\hline & & Penutupan masalah & 1 \\
\hline \multicolumn{2}{|c|}{ Total aktivitas } & & 5 \\
\hline \multirow[t]{10}{*}{4} & IT Support & Idenfikasi Masalah & 1 \\
\hline & Officer & $\begin{array}{l}\text { Pencatatan masalah yang } \\
\text { muncul }\end{array}$ & 3 \\
\hline & & Pengkategorian masalah & 1 \\
\hline & & Memprioritaskan Insiden & 1 \\
\hline & & $\begin{array}{l}\text { Investigasi dan diagnosa } \\
\text { masalah }\end{array}$ & 1 \\
\hline & & Menemukan solusi. & 1 \\
\hline & & $\begin{array}{l}\text { Mengulas kembali } \\
\text { rekaman permasalahan } \\
\text { yang di catat. }\end{array}$ & 1 \\
\hline & & $\begin{array}{l}\text { Meyelesaikan masalah } \\
\text { setelah menemukan solusi. }\end{array}$ & 1 \\
\hline & & Penutupan masalah & 1 \\
\hline & & Mengulas masalah utama & 4 \\
\hline \multicolumn{2}{|c|}{ Total aktivitas } & & 15 \\
\hline \multirow[t]{2}{*}{5} & IT & Idenfikasi Masalah & 1 \\
\hline & Programmer & $\begin{array}{l}\text { Meyelesaikan masalah } \\
\text { setelah menemukan solusi. } \\
\text { Mengulas masalah utama }\end{array}$ & 1 \\
\hline \multicolumn{2}{|c|}{ Total aktivitas } & & 5 \\
\hline
\end{tabular}

Daftar aktifitas dan aktor yang telah disepakati akan dimasukan kedalam rancangan SOP yang disuaikan dengan template SOP yang diajukan oleh pihak IT, dapat dilihat pada Gambar 3.

\begin{tabular}{|c|c|c|c|c|}
\hline \multirow{2}{*}{$\begin{array}{l}\text { PT.XYZ } \\
\text { Surabaya }\end{array}$} & \multicolumn{4}{|c|}{ JUDUL AKTIVITAS } \\
\hline & \multirow{3}{*}{$\begin{array}{c}\text { NODOKUMEN } \\
\text { TANGGAL } \\
\text { TERBIT }\end{array}$} & \multirow{2}{*}{\multicolumn{2}{|c|}{$\begin{array}{l}\text { NO REVISI } \\
\text { DIBUAT OLEH }\end{array}$}} & \multirow{2}{*}{$\begin{array}{l}\text { HALAMAN } \\
\text { DISAHKAN } \\
\text { OLEH }\end{array}$} \\
\hline \multirow{2}{*}{ NAMA SOP } & & & & \\
\hline & & \multicolumn{2}{|r|}{ (HRD) } & (DIREKSI) \\
\hline \multicolumn{5}{|l|}{ 1. PENJELASAN NAMA SOP } \\
\hline \multicolumn{5}{|l|}{ 2. TUJUAN } \\
\hline 3. PROSEDUR & $\begin{array}{l}\text { 4. UNIT YANG } \\
\text { BERTANGGU } \\
\text { JAWAB }\end{array}$ & & 5. D & UMEN OUTPUT \\
\hline & & & & \\
\hline
\end{tabular}

Gambar 3. Template SOP baru

Proses verifikasi adalah proses terakhir dari tahap pembuatan SOP Problem management TI. Proses verifikasi ini dilakukan dengan cara membuat SOP dari hasil penyesuaian dokumen SOP yang dibuat berdasarkan template SOP dari pihak TI yang telah diperbaharui lalu dikomunikasikan dengan kembali dengan pihak TI.

Hasil SOP yang telah dikomunikasikan tersebut menghasilkan SOP yang benar benar sesuai dengan kebutuhan pihak TI di perusahaan, keseluruhan dokumen SOP problem management mampu menjawab kebutuhan perusahaan untuk mengelola masalah IT. Tetapi setelah mengkomunikasikan dokumen SOP diketahui pengetahuan staf TI terkait problem management perlu untuk ditingkatkan terlebih dahulu sebelum melakukan penerapan proses problem management. Hal ini diperlukan agar proses problem management yang dijalankan berjalan sesuai dengan prosedur dan tidak ada hambatan yang terjadi karena kurangnya pengetahuan staf TI mengenai problem management.

\section{Kesimpulan}

Penyusunan dokumen SOP problem management disusun untuk perusahaan ekspor di Surabaya. Literatur yang digunakan untuk menyusun dokumen SOP problem management adalah "ITIL: Problem management" dan "COBIT 5: DSS 03 Manage Problem". Dokumen SOP problem management terdiri dari 11 prosedur serta 5 aktor. Terdapat 5 peran yang akan melaksanakan problem management yaitu: IT Support 15 aktivitas, IT Manager 15 aktifitas, IT Programmer 5 aktivitas, General Manager 1 aktivitas, dan IT Dokumen 2 aktivitas.

Dalam penelitian ini diperlukan suatu pengembangan untuk penelitian selanjutnya. Pengembangan ini diperlukan guna memperluas ruang lingkup proses problem management TI. Halhal yang dapat di kembangkan meliputi: evaluasi kesesuaian SOP dengan pelaksanaan yang terdapat di perusahaan, dan pengukuran maturity level.

\section{Daftar Pustaka}

Budihardjo, M., 2014. Panduan Praktis Menyusun SOP Standar Operating Procedure. Yogyakarta: Gajah Mada University Press.

Cabinet Office, 2011. ITIL Service Design. Norwich: UK: The Stationery Office Limited.

Chen, J.-S., Tsou, H.-T., 2007. Information technology adoption for service innovation and firm performance. Proceedings - ICSSSM'06: 2006. International Conference on Service Systems and Service Management, 1(3), 472-477. 08

Glenfis, 2012. ITIL Edition 2011 - COBIT 5 Mapping. USA: Glenfis.

ISACA, 2012. COBIT 5 Enabling Processes. USA: ISACA.

IT Service Management Forum, 2007. An Introductory Overview of ITIL V3. UK: The UK Chapter of the itSMF.

Megawati, K.S., 2012. Usulan Tata Kelola 
Manajemen Insiden dan Masalah Berdasarkan Kombinasi COBIT 4.1 dan ITIL V3, 2012(Snati), $15-16$.

OGC, 2011a. ITIL Service Operation. London: The Stationery Office.

OGC, 2011b. ITIL Service Operation (Version 20). London: The Stationery Office.

OGC, 2011c. ITIL Service Operation. London: The Stationery Office.
Putra, R.D., Darwiyanto, E., 2016. Audit Teknologi Informasi Dengan Menggunakan Framework COBIT 5 Domain DSS ( Deliver, Service, And Support ) Pada PT . Inovasti Tjaraka Buana. EProceeding of Engineering 3(1), 930-937.

Shestakevych, T., 2018. Information and Technology Support of Inclusive Education in Ukraine. In 1st International Conference on Computer Science, Engineering and Education Applications (ICCSEEA 2018). 